\title{
The Archives Thief: The Man Who Salvaged French Jewish History in the Wake of the
}

Holocaust. By Lisa Moses Leff. New York: Oxford University Press, 2015. 286 pp. Notes, index. Hardcover. \$29.95.

Lisa Moses Leff's The Archive Thief: The Man Who Salvaged French Jewish History in the Wake of the Holocaust is a biography about Zosa Szajkowski (1911-1978), a leading historian of French Jews. Szajkowski used his knowledge of languages and Jewish history to identify and take records from archives both during and immediately after World War II. His efforts saved thousands of important historic documents on European Jews from being lost or destroyed. However, unlike the book The Monuments Men, ${ }^{1}$ which tells the heroic tale of a group of academics sent to Europe during World War II to save historic artifacts, this book does not have a happy ending. Szajkowski eventually became a thief, stealing Jewish-related documents from European and American repositories not to ensure their protection from immediate physical danger but to assist him in his own research and, later, to sell for a profit.

As a biography, this is a fascinating story. Szajkowski was a Polish-born Jew whose neighborhood was destroyed in World War I. Szajkowski migrated to Paris at 16 and eventually became acquainted with and influenced by a number of Jewish intellectuals who had fled the rise of anti-Semitism in Germany and elsewhere in Europe. He fought the Nazis as a member of the French Foreign Legion and was severely wounded in 1940. After escaping to America in 1941, he joined the US Army and returned to Europe in 1943 as a paratrooper. As a displaced Jew and a budding historian, Szajkowski had become dedicated to the idea of documenting the Jewish record for posterity. While recuperating from his wounds in unoccupied France, he began collecting historic Jewish documents and shipping them out of France. He continued this practice while serving in the US Army. In the postwar period, he expanded his efforts to save materials in Germany that pertained to the Nazi treatment of the Jews. Some of this material was later used to prosecute Nazis for war crimes. In his later life, Szajkowski became a prolific author but was ostracized from the historian community both because of his lack of formal training and because of questions about how he obtained his material. He took his life in 1978, a few days after being caught stealing parts of a rare collection of pamphlets from the New York Public Library.

However, this book is much more than a mere biography. In writing the tale of Szajkowski, Leff deftly explains the role of archives, especially how archives relate to the idea of nationhood. She argues that to possess an archives is to possess the history and legitimacy of a nation. But, does a nation have to be defined by a geographical area? After witnessing how Jews and records pertaining to them could be and were eliminated in Europe, Szajkowski and others sought to preserve these records by permanently removing them to safe areas, most notably to institutions in the United States or Israel. Once preserved, the idea of a Jewish people, regardless of where they live, could be documented.

Szajkowski's work during the war most undoubtedly helped preserve many important records that would otherwise have been destroyed. However, to take from the public record because of a different idea of nationhood is a questionable and even harmful practice. Worse, as Europe stabilized following the war, he continued taking records, 
both as a researcher and a dealer. As a researcher, he re-arranged and even marked these records to suit his particular field of study. As a dealer, he often sold parts of collections to different buyers, leading to a wide disbursement of records from the same collection. One does not have to be an archivist to understand the problems associated with his actions, but Leff does an outstanding job of explaining the detrimental effects of these actions on future researchers, on the provenance of the records, and on the archives and repositories themselves.

Leff is uniquely qualified to write this account. She is a professor of European history at American University in Washington, DC, and her research focuses on the Jews in France. She is familiar with the many scholarly works that Szajkowski produced (in several different languages) as well as with the people, sources, and institutions Szajkowski interacted with when conducting his research and selling his materials. As such, she handles this complicated material well. Leff is able to provide a sound critique of both the works of Szajkowski and his sources, but, just as important, she does so in a way understandable to a nonexpert in the field. Similarly, her explanations on the importance of issues as diverse as provenance, the culture of an archives, and the failure to build a centralized repository for Jewish scholarship, are done in ways that a nonarchivist will not find too technical. Finally, explaining the context of Jewish intellectual thought in Europe during the turbulent twentieth century is well done. This is important, because, while such context does not make Szajkowski a sympathetic character, it does provide for an understanding of his motives.

Using Szajkowski's sales of records to various institutions as examples, Leff concludes her book by noting that researchers should take into account the factors that shape an archives. She states that such an understanding might make an archives look less like a coherent monument and more like a salvage heap. Why an archives is created and how it obtains its materials is important to know, but Leff's conclusion is a little harsh. Historians know that they are at the mercy of incomplete evidence and records, as well as the biases in those records and even of those who preserve them. True archivists attempt to bring as much sense and structure to the records as possible, making their institutions much more than random piles of materials.

The Archives Thief tells an interesting story while also providing superb insight into the archives and history professions. Leff's writing style makes this a very accessible read for the nonarchivist, but her insights on the archival profession, which are not always flattering, also make this a valuable book for archivists.

David Joens

Director Illinois State Archives

\section{NOTE}

1. Robert M. Edsel, The Monuments Men: Allied Heroes, Nazi Thieves, and the Greatest Treasure Hunt in History (New York: Center Street, 2009). 